\title{
Pollen analysis of the crop contents of adult Oedemeridae (Coleoptera) in Bulgaria
}

\author{
JuLIANA ATANASSOVA and OgNYAN SIVILOV \\ Sofia University “St. Kliment Ohridski”, Faculty of Biology, 8 Dragan Tsankov Blvd., BG-1164 Sofia, Bulgaria; \\ e-mail: atanassova_juliana@abv.bg; osivilov@gmail.com
}

Key words. Coleoptera, Oedemeridae, adults, pollen analysis, food plant spectrum

\begin{abstract}
Pollen analysis of crop samples was used to identify the food sources of species of beetles of the family Oedemeridae in Bulgaria. A total of 21 species and subspecies were examined; pollen was present in the crops of 18 of the species. Our study is the first to provide information on the food sources of four species and subspecies: Chrysanthia varipes varipes, Anogcodes seladonius turcicus, A. ruficollis and Oedemera flavicans. New data on food sources for many of the other species studied was obtained and feeding on pollen of gymnosperms and honeydew by some of the species was confirmed. Possible mechanisms for digesting pollen are discussed. There was no evidence of either the pollen germinating or being predigested in the crop of the beetles.
\end{abstract}

\section{INTRODUCTION}

The coleopteran family Oedemeridae, known as "pollen-feeding beetles" and also as "false blister beetles", comprises at least 100 genera with 1500 species distributed worldwide (VazquezAlbalate, 2002). The family is taxonomically quite well studied, with 79 to 94 species occurring in Europe depending on the different geographical boundaries used by the authors. A total of 34 species are reported from Bulgaria (Vazquez-Albalate, 2002; Švihla, 2008). All stages are phytophagous and saproxylic; larvae feed in moist rotting wood or stems of herbaceous plants, while most adults are obligate pollen feeders and often function as pollinators of a variety of plant families (Murphy \& Vasseur, 1995; Arnett, 2000; Carloni \& Bologna, 2005; Pellegrino et al., 2005). However, the precise food sources utilized by adult beetles of most species are unknown.

Pollen is a highly nutritious food, containing proteins, minerals, lipids, carbohydrates and fibre, but the resistant outer wall (exine) of pollen grains presents an obstacle that pollen-feeders must overcome. Moreover, there is great variation in the nutritional quality of the pollen of different plant species, especially with respect to protein content, which can range from 2.5 to $61 \%$ (Roulston \& Cane, 2000). The knowledge of the mechanisms used by pollen-feeders to ingest pollen grains (pseudo-germination, exudation, microbial digestion or enzyme penetration) is poor. Very little is known about pollen feeding by beetles, especially the Oedemeridae (Johnson \& Nicolson, 2001). Most information about the food plants comes from direct observation of feeding individuals (Vazquez-Albalate, 2002; Kubisz, 2006). Recently, pollen found on/in a pollinator was used to determine its food plants, migratory activities and habitat (Jones, 2012).

The aim of the present study is to establish the food sources of Oedemeridae in Bulgaria based on a qualitative pollen analysis of the contents of their crops. The present investigation provides information not only on the food source at the moment of feeding but also on the plants previously visited. The first preliminary information on the food plant spectrum of the Oedemeridae beetles in Bulgaria was published by Sivilov et al. (2011). The present study is an extension of that project and reports information based on 78 crop pollen samples of 18 species and subspecies of Oedemeridae.

\section{MATERIAL AND METHODS}

\section{Methods of collecting beetles}

Individuals of 21 species and subspecies of Oedemeridae were collected on a mountain massif (Pirin Mts) and in the southern part of the Struma River Valley in Southwestern Bulgaria (Fig. 1). Two samples only of Sparedrus testaceus Andersch, 1797 were collected at one site in Northwest Bulgaria. These localities were visited several times in 2008 and 2010 during the period AprilAugust.

The following methods of collecting were used: sweeping herbaceous vegetation and shrubs (main method), direct collecting by hand and using forceps, beating and brushing, and light trapping of nocturnal species. The adult specimens were dissected under a stereomicroscope and the pollen extracted from the crop was preserved in glycerol. In fact the samples of pollen from the "crop" contain pollen from both the crop and oesophagus. The beetles were dissected by pulling their heads off, which resulted in the digestive system being severed in the area of the proventriculus. The esophagus with the sac-like diverticulum (crop, ingluvie) (Fig. 2) are extracted simultaneously from the body along with the head. In the next step the crop is placed in a drop of glycerol on a cavity glass slide where the pollen is extracted. Before studying under a light transmitting microscope, mixed pollen samples were prepared. Each mixed sample included pollen from all the specimens of one species collected at one locality on the same day. Dissected specimens were preserved in one of two ways; most specimens were embedded in cotton wool in cardboard boxes and some were restored and glued to paper board. Two samples per specimen were collected from Sparedrus testaceus, from the stomodaeum (ingluvie) and proctodaeum, respectively.

\section{Pollen analysis}

The pollen samples were prepared without chemical treatment as recommended by Jones (2012). Acetolyzation, a chemical treatment that removes lipids from the pollen grains so that the fine details can be seen more easily (Erdtman, 1969; Faegri et al., 1989), is frequently used in palynology. However, this process affects some thin walled pollen grains and many of the fungal elements, making it unsuitable for the current study. Microscopic analysis was done using transmitted light microscopy at a $400 \times$ 


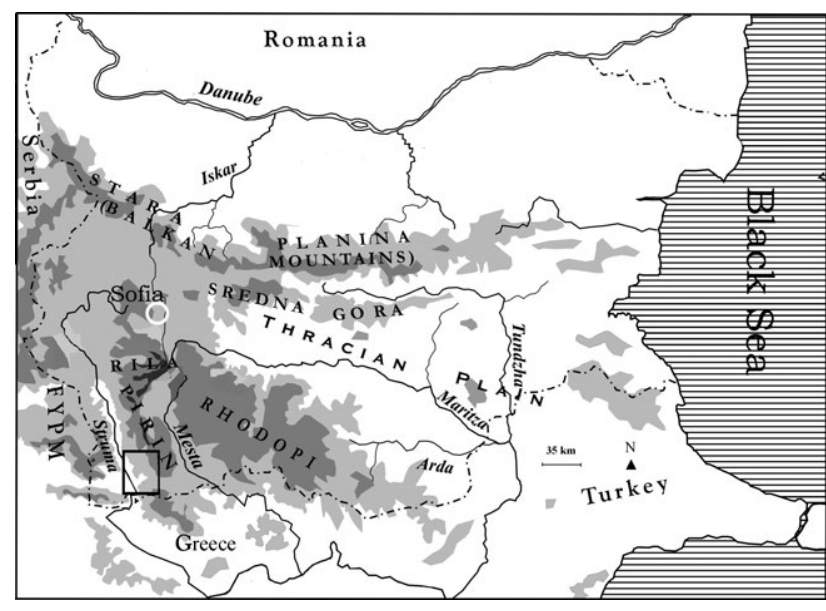

Fig. 1. Map of Bulgaria with the study site in the Pirin mountains enclosed by a small square.

magnification. To increase the precision of the identification, pollen grains were measured using an ocular and stage micrometer. For pollen identification a pollen reference collection from the sites studied was used and the key by Beug (2004). It is a wellknown fact that some pollen grains cannot be identified to genus or species, therefore pollen grains with very similar morphologies, but possibly belonging to different species or genera, are assigned to larger groups (Faegri et al., 1989; Moor et al., 1991; Beug, 2004). The term "pollen type" is used in palynology in such cases. At least 600 pollen grains in each crop sample were identified. The frequency of each pollen type in the pollen sample was expressed as a percentage. This qualitative pollen analysis indicates the relative proportions of the different pollen types in the pollen spectrum (Faegri et al., 1989). The pollen type with the highest percentage in each crop sample was designated the dominant pollen type; all other pollen taxa in the pollen spectra were designated as secondary pollen types. Figs 3-5 display the main pollen types in the pollen spectra. The complete list of pollen taxa identified for each Oedemeridae species and information on where the beetles were collected can be found in the "Results" section. Some of the crop samples contained fungal elements - spores and conidia, especially of sooty moulds (dark pigmented fungi that are non-parasitic, saprophytic and superficial on plants). These fungi tend to assume various shapes and frequently grow on honeydew, a sweet, clear and sticky substance excreted by sap-sucking insects like aphids mainly on trees and shrubs. The fungal elements were also counted, but not included in the pollen sum.

Microphotographs were taken of important pollen types and fungal elements in crop samples (Fig. 6).

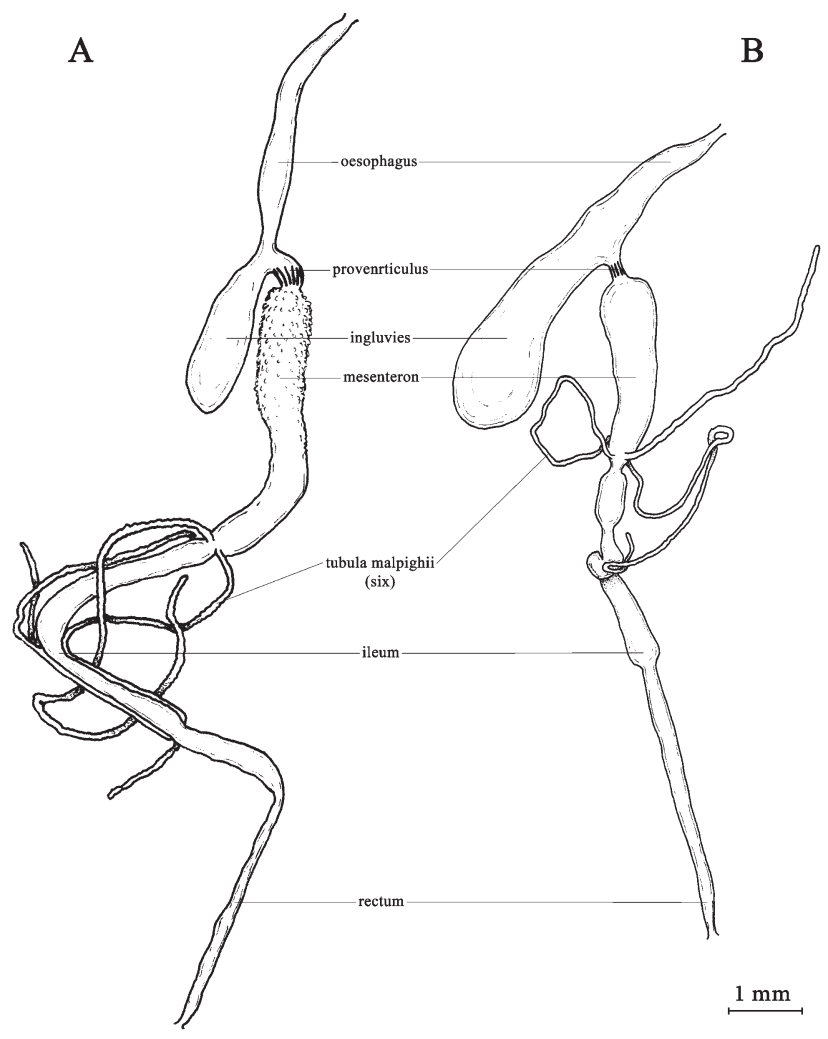

Fig. 2. A - Alimentary canal of Oedemera flavicans; B - Alimentary canal of Oedemera femorata.

\section{RESULTS}

Crop samples from 21 species and subspecies of Oedemeridae were examined, and pollen was found in 18 of them. The taxonomy of the beetles is based on the systematic treatment of Vasques (2002) with minor modifications. No pollen grains were found in the crops of three species: Calopus serraticornis (Linnaeus, 1758), Nacerdes (s. str.) melanura (Linnaeus, 1758) and Anogcodes rufiventris (Scopoli, 1763) - for which only one specimen of each was collected. The dominant and secondary pollen taxa are presented below for each genus and species. This pollen analysis was used to construct the food plant spectra presented in the following sections:

\section{Genus Sparedrus}

S. testaceus Andersch, 1797 - this species occurs in forests in the lower mountain belt (0-800 $\mathrm{m}$ a.s.1.). Dominant pollen: Pinus (Pinaceae) (Fig. 3), (Fig. 6A); secondary pollen: Rhamnus type (including pollen of Paliurus) (Rhamnaceae), Quercus

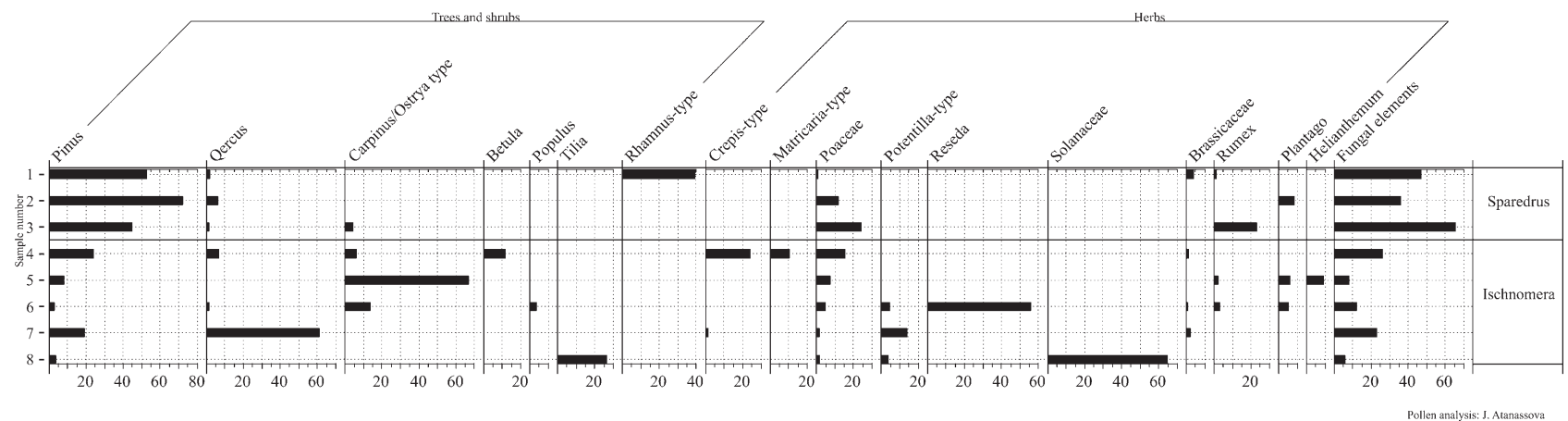

Fig. 3. Sparedrus and Ischnomera - results of the pollen analysis in terms of the \% of each type of pollen present in each sample. Sample number: 1-3-Sparedrus testaceus; 4-8 - Ischnomera cyanea. 


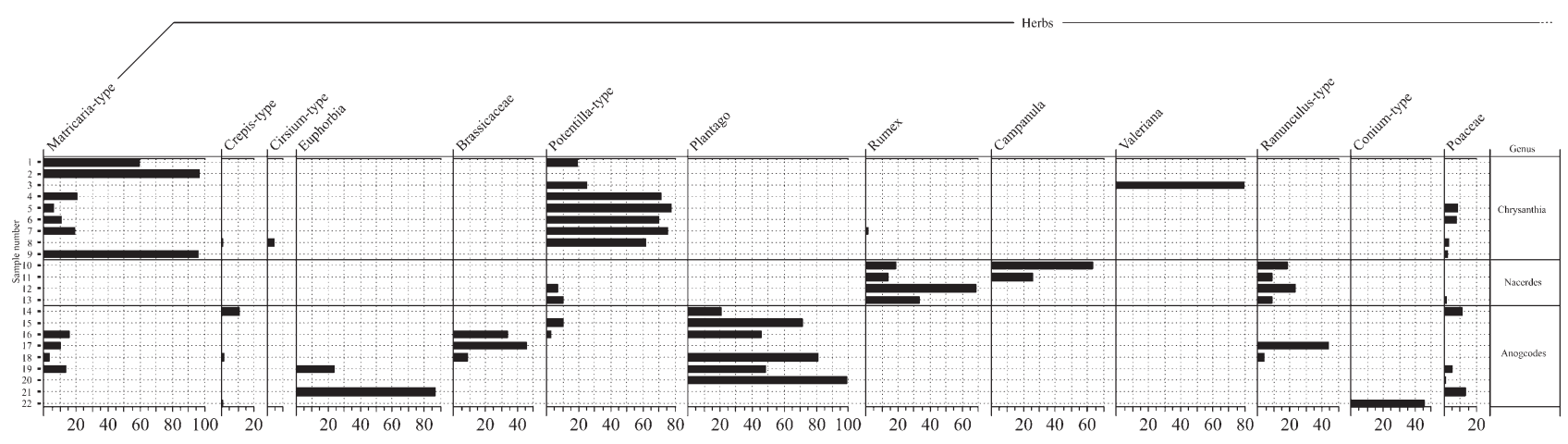

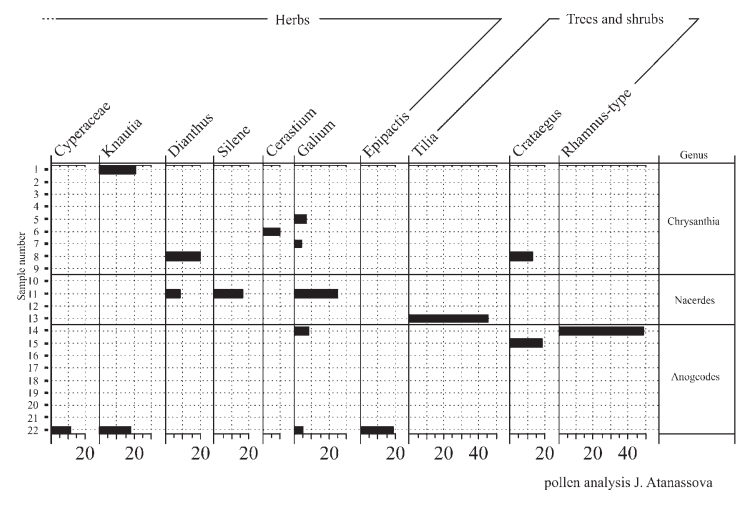

(Fagaceae), Carpinus/Ostrya type (including pollen of Carpinus betulus, Carpinus orientalis and Ostrya carpinifolia) and Alnus (Betulaceae), Rumex (Polygonaceae), Plantago (Plantaginaceae), Poaceae, Brassicaceae. High values for fungal elements were also recorded.

In the two samples from different parts of the digestive system, of beetles collected at one site in Northwest Bulgaria, pol-
Fig. 4. Chrysanthia, Nacerdes and Anogcodes - results of the pollen analysis in terms of the \% of each type of pollen present in each sample. Sample number: 1-6-Chrysanthia viridissima; 7-8 - C. geniculata geniculata; 9 - C. varipes varipes; $10-13-$ Nacerdes carniolica carniolica; 14 - Anogcodes melanurus; 15-17 - A. seladonius turcicus; 18-22-A. ruficollis.

len of Carpinus/Ostrya type and Quercus were present, but in concentrations too low for pollen analysis. The main content of the digestive tract in this beetle consisted of fungal elements (Fig. $6 \mathrm{~B}-6 \mathrm{D})$.
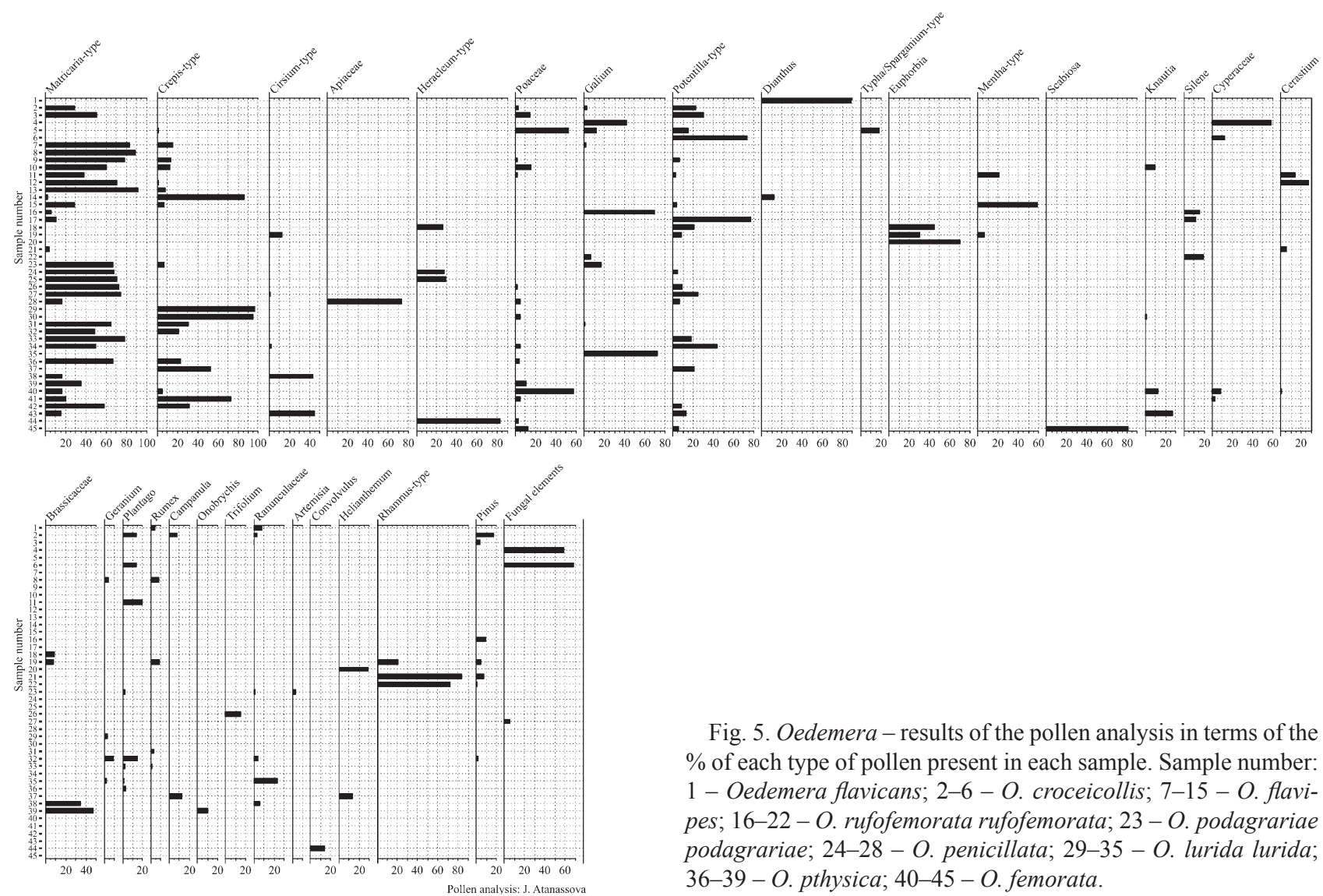

Fig. 5. Oedemera - results of the pollen analysis in terms of the $\%$ of each type of pollen present in each sample. Sample number: 1 -Oedemera flavicans; 2-6-O. croceicollis; 7-15-O. flavipes; 16-22 - O. rufofemorata rufofemorata; 23 - O. podagrariae podagrariae; 24-28 - O. penicillata; 29-35 - O. lurida lurida; 36-39-O. pthysica; 40-45-O. femorata. 


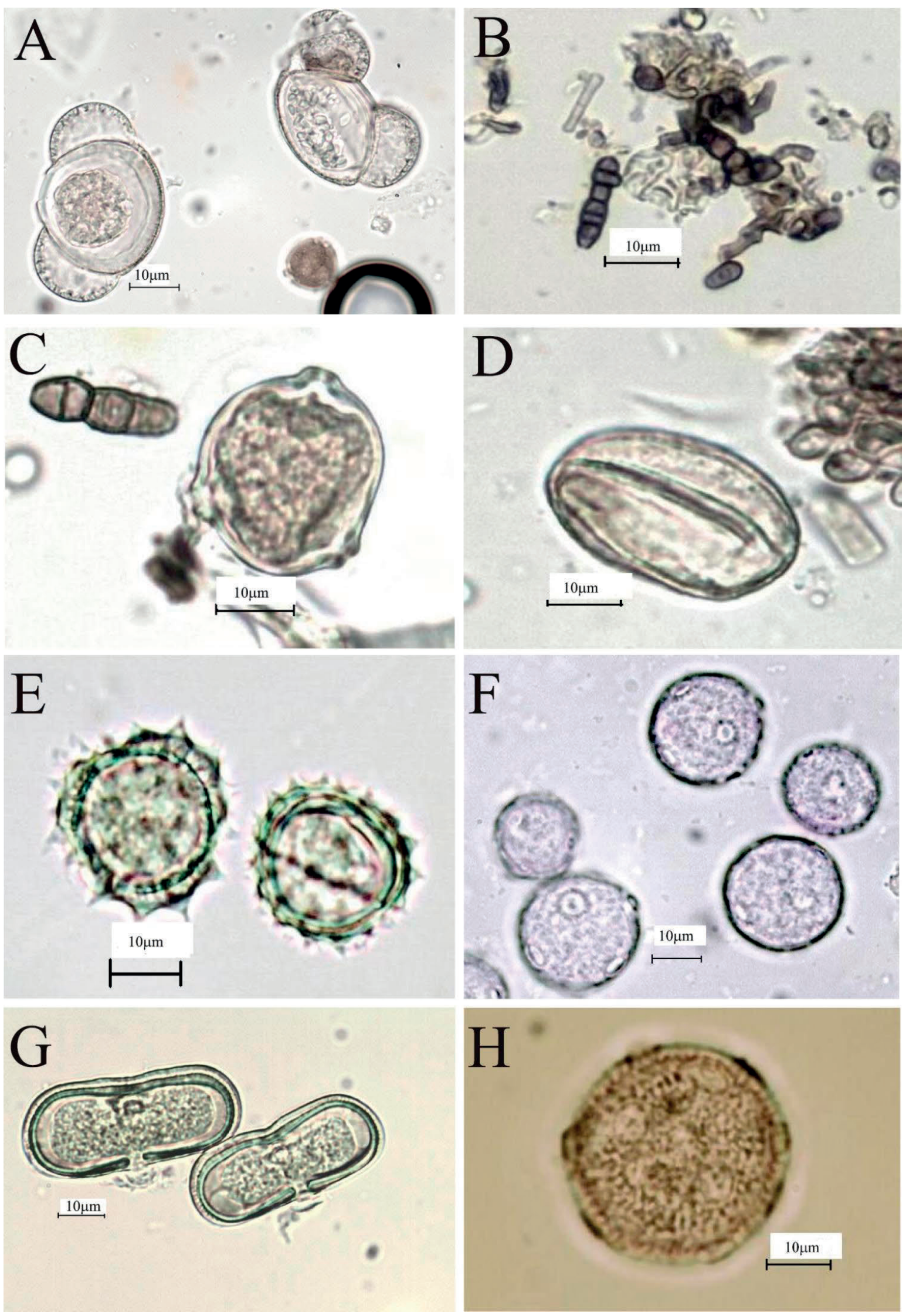

Fig. 6. Microscopical photographs of the main types of pollen found in the crop and proctodeum samples of Oedemeridae beetles. A - Pinus pollen from crop of Sparedrus testaceus; B - fungal elements from crop of Sparedrus testaceus; C - Carpinus/Ostrya type and fungal elements in sample from proctodaeum of Sparedrus testaceu; D - Quercus pollen in sample from proctodaeum of Sparedrus testaceus; E - Matricaria type from crop of Chrysanthia varipes varipes; F - Plantago pollen from crop of Anogcodes melanurus; $\mathrm{G}$ Pollen grains of Apiaceae from crop of Anogcodes ruficollis; $\mathrm{H}$ - Dianthus pollen from crop of Oedemera flavicans. 


\section{Genus Chrysanthia}

C. viridissima (Linnaeus, 1758) - found in meadows in the lower and middle mountain belt (300 - $1800 \mathrm{~m}$ a.s.1.). Dominant pollen: Matricaria type (including pollen of Achillea, Anthemis, Chrysanthemum, Leucanthemum and Tanacetum - Asteraceae), Potentilla type (including pollen of Fragaria, Rosaceae), Valeriana (Valerianaceae) (Fig. 4); secondary pollen: Epilobium (Onagraceae), Galium (Rubiaceae), Knautia (Dipsacaceae), Cerastium (Caryophyllaceae), Lotus and Trifolium (Fabaceae), Mentha type (including pollen of Acinos, Calamintha, Lycopus, Origanum and Thymus - Lamiaceae), Pinus, Poaceae.

C. geniculata geniculata (Schmidt, 1846) - found in meadows in mountain belt at $1400 \mathrm{~m}$ a.s.l. (Southern Pirin Mts.). Dominant pollen: Potentilla type (Fig. 4); secondary pollen: Matricaria type, Cirsium (Asteraceae), Crepis type (including pollen of $\mathrm{Hi}$ eracium, Hypochaeris, Leontodon and Taraxacum - Asteraceae), Dianthus (Caryophyllaceae), Galium, Crataegus (Rosaceae), Rumex.

C. varipes varipes Kiesenwetter, 1861 - found in a meadow at a low altitude. Dominant pollen: Matricaria type (Figs 4, 6E); secondary pollen: Centaurea cyanus (Asteraceae), Poaceae (Fig. 4).

\section{Genus Nacerdes}

N. (Xanthochroa) carniolica carniolica (Gistel, 1834) - found in a forest in the Pirin and Slavjanka Mts (400-2000 m.a.s.1.). Dominant pollen: Campanula (Campanulaceae), Galium, Rumex, Tilia (Tiliaceae) (Fig. 4); secondary pollen: Silene, Dianthus (Caryophyllaceae), Artemisia (Asteraceae), Chenopodiaceae, Mentha type and Salvia (Lamiaceae), Poaceae, Potentilla type, Ranunculus type (Ranunculaceae); fungal elements.

\section{Genus Anogcodes}

A. melanurus Fabricius, 1787 - found in the southern part of the Struma river valley in South Western Bulgaria. Dominant pollen: Rhamnus type (Fig. 4); secondary pollen: Crepis type, Galium, Plantago, Poaceae; Fungal elements.

A. seladonius turcicus (Schmidt, 1846) - occurs in grassland in the lower and middle mountain belt up to $1300 \mathrm{~m}$ a.s.1. Dominant pollen: Plantago (Fig. 6F), Brassicaceae, Ranunculus type (Fig. 4, sample 15-17); secondary pollen: Matricaria type, Potentilla type, Sorbus (Rosaceae), Convolvulus (Convolvulaceae), Brassicaceae.

A. ruficollis (Fabricius, 1781) - this species occurs in meadows in the lower hilly zone (up to $700 \mathrm{~m}$ a.s.1.) in South Western Bulgaria. Dominant pollen: Plantago, Apiaceae (Fig. 6G), Euphorbia (Euphorbiaceae) (Fig. 4); secondary pollen: Crepis type, Matricaria type, Artemisia, Brassicaceae, Cyperaceae, Epipactis (Orchidaceae), Galium, Knautia, Poaceae, Ranunculus type, Scrophulariaceae; fungal elements.

\section{Genus Ischnomera}

I. cyanea (Fabricius, 1792) - collected in a meadow near deciduous forest and in deciduous forests (0-1500 m a.s.1.). Dominant pollen: Quercus, Carpinus/Ostrya type, Crepis type, Pinus, Reseda (Resedaceae), Solanaceae (Fig. 3); secondary pollen: Betula (Betulaceae), Brassicaceae, Helianthemum (Cistaceae), Matricaria type, Plantago, Poaceae, Populus (Salicaceae), Potentilla type, Rosa, Rumex, Sambucus (Caprifoliaceae), Tilia; fungal elements.

\section{Genus Oedemera}

O. flavicans, O. croceicollis and O. rufofemorata were found in a meadow at a low altitude. All other Oedemera species occur commonly over a wide range of altitudes from 0 to $1000-1500 \mathrm{~m}$ a.s.l. in grassland of different types.
O. (Oncomera) flavicans (Fairmaire, 1860) - dominant pollen: Dianthus (Fig. $6 \mathrm{H}$ ); secondary pollen: Ranunculaceae, $R u$ mex (Fig. 5).

O. (s. str.) croceicollis (Gyllenhall, 1827) - dominant pollen: Matricaria type, Potentilla type, Cyperaceae, Poaceae (Fig. 5); secondary pollen: Campanula, Crepis type, Galium, Geranium (Geraniaceae), Pinus, Plantago, Ranunculaceae, Ranunculus type, Typha/Sparganium type (Typhaceae/Sparganiaceae); fungal elements.

O. (s. str.) flavipes (Fabricius, 1792) - dominant pollen: Crepis type, Matricaria type, Mentha type (Fig. 5); secondary pollen: Dianthus, Echium (Boraginaceae), Galium, Geranium, Knautia, Salvia, Plantago, Poaceae, Potentilla type, Ranunculaceae, Rosaceae, Rumex, Cerastium.

O. (s. str.) rufofemorata rufofemorata (Germar, 1824) - dominant pollen: Euphorbia, Galium, Potentilla type, Rhamnus type (Fig. 5); secondary pollen: Artemisia, Brassicaceae, Cirsium, Dianthus, Helianthemum, Heracleum type (Apiaceae), Matricaria type, Mentha type, Pinus, Rumex, Cerastium, Silene; fungal elements.

O. (s. str.) podagrariae podagrariae (Linnaeus, 1767) - dominant pollen: Matricaria type (Fig. 5); secondary pollen: Artemisia, Crepis type, Galium, Poaceae.

O. (s. str.) penicillata Schmidt, 1846 - dominant pollen: Apiaceae, Matricaria type (Fig. 5); secondary pollen: Cirsium, Heracleum type, Poaceae, Potentilla type, Trifolium (Fabaceae); fungal elements.

O. (s. str.) lurida lurida (Marsham, 1802) - dominant pollen: Crepis type, Galium, Matricaria type, Potentilla type (Fig. 5); secondary pollen: Cirsium, Geranium, Knautia, Pinus, Plantago, Poaceae, Ranunculaceae, Rumex.

O. (s. str.) pthysica (Scopoli, 1763) - dominant pollen: Brassicaceae, Cirsium, Crepis type, Matricaria type (Fig. 5); secondary pollen: Campanula, Helianthemum, Onobrychis (Fabaceae), Plantago, Poaceae, Potentilla type, Ranunculus type.

O. (s. str.) femorata (Scopoli, 1763) - dominant pollen: Cirsium, Heracleum type, Crepis type, Matricaria type, Poaceae, Knautia, Scabiosa (Dipsacaceae) (Fig. 5, sample 40-45); secondary pollen: Cerastium, Convolvulus, Cyperaceae, Geum (Rosaceae), Potentilla type, Poaceae.

\section{DISCUSSION}

The food sources of four species were unknown prior to this study: Chrysanthia varipes varipes, Anogcodes seladonius turcicus, A. ruficollis and Oedemera (Oncomera) flavicans. In addition new information was obtained on the food sources for many of the other taxa studied.

Two species $-S$. testaceus and I. cyanea use the pollen of a wide range of arboreal and some herbaceous species of plants as food. Pinus pollen together with pollen of shrubs belonging to the families Fagaceae, Betulaceae and Rhamnaceae, and deciduous trees such as Tilia seem to be very important (Fig. 3). Sivilov et al. (2011) was the first to report feeding of European oedemerids on gymnosperms and this is confirmed by the current study. In the literature, I. cyanea is reported to feed only on a few tree genera (Acer, Crataegus, Salix, Sorbus, Quercus, Fagus, Populus, Ulmus and Castanea) and on herbaceous plants of the family Apiaceae (Vazquez-Albalate, 2002; Kubisz, 2006). The large amounts of fungal elements together with pollen suggest that honeydew is an important food source for these beetles. Pieces of plant tissue were also present in these samples.

The pollen analysis indicates that adults of the species of Chrysanthia studied preferred pollen of plants belonging to Asteraceae and Rosaceae. For Anogcodes pollen of Plantago dominated but Rhamnus type, Euphorbia and Apiaceae were also important 
(Fig. 4). However, further investigation is necessary to complete the list of plants used as food sources by species of the genus Chrysanthia, Nacerdes and Anogcodes in Bulgaria.

Forty-five crop pollen samples from nine species of Oedemera contained pollen from a wide variety of herbaceous plant taxa, with that of Asteraceae dominant in $60 \%$ of all Oedemera crop samples. Matricaria type pollen was dominant in $44 \%$ of the samples and present in $68 \%$ of the crop samples. Crepis type pollen was dominant in $11 \%$ and present in $35 \%$ of the samples. Cirsium pollen was also important. The preference for Asteraceae and Apiaceae pollen is reported for O. flavipes and O. lurida in central Italy (Carloni \& Bologna, 2005). Our analysis showed a predominance of Apiaceae pollen (including Heracleum-type) in one sample from $O$. penicillata and one from $O$. femorata. Pollen of Potentilla type is common (in $36 \%$ of the samples) but was dominant in only 2 samples. It is likely that Apiaceae, Euphorbia, Galium, different Lamiaceae, Poaceae, Cyperaceae, Scabiosa, Dianthus and other secondary taxa are alternative important food sources, especially in periods when species of Asteraceae are not flowering. Pollen of the dominant Rhamnus type (most probably Paliurus spina-christi, the only species of Rhamnaceae flowering during this study) was the only shrub pollen type in O. rufofemorata crop samples. Pinus pollen and fungal elements were usually only sporadically present, with the exception of one sample from $O$. croceicollis, which contained abundant fungal remains. The food spectrum of $O$. penicillata was previously unknown and we have established that this species fed mainly on Matricaria type pollen.

The absence of pollen in crop samples of Calopus serraticornis, Nacerdes (s. str.) melanura and Anogcodes rufiventris may due to their having only very recently emerged and/or an insufficient number of specimens sampled.

In conclusion, the results of the pollen analysis demonstrated that the adults of the species of Oedemeridae studied are polyphagous, and most of them do not show any preference for particular plant families and genera as food sources. We consider that these insects are opportunists and in certain circumstances some oedemerids also use honeydew as a highly nutritional food. Nevertheless, three groups can be distinguished based on their preferences for pollen from herbaceous and arboreal plants. The genus Sparedrus feeds mainly on honeydew and pollen from trees and bushes and rarely feeds on pollen from herbaceous plants. In contrast, species of the genera Chrysanthia, Nacerdes, Anogcodes and Oedemera feed almost entirely on pollen of herbaceous plants and very rarely consume that of trees and shrubs. Representatives of the genus Ischnomera have an "intermediate" position: they feed on the widest range of food sources and feed on pollen (from trees, shrubs and herbaceous plants) and honeydew in equal proportions.

\section{Possible mechanisms of digesting pollen}

The pollen grains ingested by Oedemeridae beetles are initially stored in their crops (ingluvies). According to Samuelson (1994) this sac-like diverticulum also contains nectar which may induce the germination of the pollen grains. Our investigations of over 70 crop pollen samples did not confirm this hypothesis. There was no evidence that pollen grains germinated in the crop. Similarly, pollen in samples from the proctodaeum of Sparedrus testaceus also had not germinated. Most of the pollen grains were intact, undistorted and the exine undamaged (Fig. 6). These facts suggest that the extraction of nutrients from pollen grains occurs simply by penetration of digestive enzymes via the apertures in the wall of the pollen grains and extraction of the protoplas- mic contents from inside the grain (Johnson \& Nicolson, 2001). However, more specialized studies are needed to clarify the exact mechanism of digestion.

ACKNOWLEDGEMENTS. The authors thank M.A. Bologna (Dipartimento di Scienze, Università Roma Tre) for providing literature and P. Mudie for improving the English. This study was supported by Grant No. 006/30.03.2010 of Scientific Research Fund, Sofia University St. Kliment Ohridski.

\section{REFERENCES}

ARNetT R.H. JR. 2000: False Blister Beetles (Insecta: Coleoptera: Oedemeridae). http://edis.ifas.ufl.edu/in311. 21/03/2013.

Beug H.J. 2004: Leitfaden der Pollenbestimmung für Mitteleuropa und angrenzende Gebiete. Dr. Friedrich Pfeil, München, $542 \mathrm{pp}$.

Carloni S. \& Bologna M. 2005: Niche differences in two Oedemera species in mediterranean and continental ecosystems of central Italy (Coleoptera: Oedemeridae). - Entomol. Gener. 28: 201-211.

ERDTMAN G. 1960: The acetolysis method, a revised description. — Svensk Bot. Tidskr. 54: 561-564.

FAegri K., KalAND P.E. \& KRZYwinski K. 1989: Textbook of Pollen Analysis. 4th ed. John Wiley \& Sons, Chichester, 328 pp.

Johnson S. \& Nicolson S. 2001: Pollen digestion by flowerfeeding Scarabaeidae: Protea beetles (Cetoniini) and monkey beetles (Hopliini). - J. Insect Physiol. 47: 725-733.

JONES G. 2012: Pollen analyses for pollination research, unacetolyzed pollen. - J. Pollin. Ecol. 9: 96-107.

Kubisz D. 2006: Oedemeridae i Scraptiidae Polski (Coleoptera, Tenebrionoidea). Instytut Systematyki i Ewolucji Zwierz PAN, Krakow, 165 pp.

Moore P.D., Webi J.A. \& Collinson M.E. 1991: Pollen Analysis. Blackwell, Oxford, 216 pp.

Murphy S.D. \& VASSEUR L. 1995: Pollen limitation in a northern population of Hepatica acutiloba. - Can. J. Bot. 73: 12341241.

Pellegrino G., Gargano D., Noce M.E. \& Musacchio A. 2005: Reproductive biology and pollinator limitation in a deceptive orchid, Serapias vomeracea (Orchidaceae). - Plant Spec. Biol. 20: 33-39.

Roulston T.H. \& CANe J.H. 2000: Pollen nutritional content and digestibility for animals. - Plant Syst. Evol. 222: 187-209.

Samuelson G.A. 1994: Pollen consumption and digestion by leaf beetles. In Jolivet P.H., Cox M.L. \& Pettipierre E. (eds): Novel Aspects of the Biology of Chrysomelidae. Kluwer, Dordrecht, pp. 179-183.

Sivilov O., Atanassova J. \& Zlatkov B. 2011: Food plant spectrum of Oedemeridae species (Insecta, Coleoptera) based on pollen analysis (a preliminary study). - C. R. Acad. Bulg. Sci. (Biol.) 64: 225-230.

ŠviHLA V. 2008: Oedemeridae. In Löbl I. \& Smetana A. (eds): Catalogue of Palaearctic Coleoptera. Apollo Books, Stenstrup, pp. 353-369.

Vazquez-Albalate X. 2002: European Fauna of Oedemeridae. Argania, Barcelona, 176 pp.

Vazquez-Albalate X. 2013: Oedemeridae. In Audisio P. (ed.): Fauna Europaea: Coleoptera. version 2.5. http://www.faunaeur.org. 21/03/2013.

Received July 9, 2013; revised and accepted May 29, 2014 Prepublished online August 19, 2014 